\title{
$S$-locus genotyping on stone fruits in Hungary: a review of the most recent achievements
}

\author{
Halász, J. \\ Corvinus University of Budapest, Faculty of Horticultural Science, Department of Genetics and Plant Breeding, \\ 1118 Budapest, Villányi út 29., Hungary
}

\begin{abstract}
Summary: Central Europe can be taken as a geographical and historical connection zone between the western growing countries and Asian gene centres of Prunus tree fruits. The determination of the $S$-genotype of stone fruit (mainly almond, plum, cherries and apricot) cultivars and landraces has both practical and theoretical significance. Our group has allocated complete $S$-genotypes for more than 200 cultivars and selections of almond, Japanese plum, sweet cherry and apricot. Among Eastern European almond cultivars, two novel cross-incompatibility groups (CIGs) were identified. $S$-alleles of a related species were also shown in $P$. dulcis accessions; a fact seems to be indicative of introgressive hybridization. Our results with Japanese plum clarified and harmonized two different allele nomenclatures and formed a basis for intensive international studies. In apricot, a total of 13 new $S$-alleles were identified from Eastern European and Asian accessions. Many Turkish and North African cultivars were classified into new CIGs, III-XVII. Results suggest that the mutation rendering apricot self-compatible might have occurred somewhere in south-east of Turkey and we were successful to confirm the presumed Irano-Caucasian origin of North African apricots based on the geographical distribution of $S$-alleles. In sweet cherry, new alleles have been identified and characterized from Turkish cultivars and selections. In addition, wild sweet cherry and sour cherry $S$-alleles were also shown indicating a broader gene pool in Turkey as compared with international cultivars. We also used $S$-genotype information of Ukrainian sweet cherry cultivars to design crosses in a functional breeding program. Our results exhibit an increased number of $S$-alleles in tree fruit accessions native to the regions from Eastern Europe to Central Asia, which can be used to develop $S$-genotyping methods, to assist cultivation and draw inferences for crop evolution.
\end{abstract}

Keywords: crop evolution, Prunus, self-incompatibility, $S$-RNase

\section{Introduction}

Prunus species including almonds, plums, apricots and cherries exhibit gametophytic self-incompatibility, a genetically controlled mechanism enabling styles to reject self-pollen. This trait is governed by the polyallelic $S$-locus, in which there are two genes, the pistil S-ribonuclease (S-RNase) (McClure et al., 1989) and the pollen expressed S-haplotype specific F-box (SFB) (Ushijima et al., 2003; Entani et al., 2003). Allelic series of the $S$-locus is labelled by different letters or numbers. Pollen grains from an $S_{1} S_{2}$ anther show incompatible symptoms on the pistils of an $S_{1} S_{2}$ plant. If two different cultivars have identical $S$-genotypes, they are mutually self-incompatible (SI), in other terms they are cross- or inter-incompatible. When pollen grains bear $S$-alleles different from the pistil they will be fully compatible. Therefore, knowledge of the $S$-genotype is of crucial importance both for cultivation and breeding.

In Hungary, there are many traditional local cultivars (for example for the species, sour cherry) that are much respected even in the neighbouring countries. In addition, there are many fruit species growing as members of the natural vegetation (apple, cherry, pear etc.) throughout the territory of the Carpathian basin, and the area has a very long tradition of fruit growing. The main growing regions and exporting countries of stone fruits are the Mediterranean region in Europe and several regions in the USA but the gene centres for all these species are supposed to be around Central Asia. Therefore, Hungary, the Eastern Europe and Western Asia can be taken as geographical and historical connection zones between the main growing countries and Asian gene centres of tree fruits.

$S$-allele diversity among cultivated self-incompatible (SI) fruit trees is of great interest due to its economical importance. In addition, available wild or semi-wild germplasm in the native regions form genetic reserves and hence their analysis might have valuable implications. Our long-term study is carried out to $S$-genotype stone fruit (mainly apricot, almond, sweet cherry and plums) cultivars, landraces and wild growing accessions; and to use this information in breeding, cultivation as well as crop evolutionary studies. This review is a current revision of our contribution to the international studies of tree fruit self-incompatibility that have been first collated for the 2011 symposium of the International Workshop on Floral Biology \& $S$-Incompatibility in Fruit Species, San Michele, Italy (Halász et al., 2012).

\section{Almond (Prunus dulcis Mill.)}

Almond is a crop of warmer dry climate and Hungary lies on the northern edge of the economic production. When 
this work was started, the $S$-genotype of many Californian, Spanish, French and Italian cultivars have been known (Boskovic et al., 1997; Ortega et al., 2006; Kodad et al., 2008a). However, considering that gene centre of almond is supposed to be in China, the territory in Eastern Europe forms an intermediate region. Using $S$-genotyping techniques based on consensus PCR we found that there is an S-RNase allele in a Hungarian cultivar, 'Tétényi bötermő', which has very similar intron length as $S_{9}$ (Halász et al., 2008). It means that consensus PCR will result in false allele assignment. We designed an allele-specific primer to selectively detect this allele $\left(S_{31 \mathrm{H}}\right)$ and found that it is also present in several additional cultivars. Increasing diversity multiplies the chance of the occurrence of different $S$-alleles with matching intron sizes; therefore, consensus PCR discrimination may not have enough resolution power.

The complete $S$-genotype was determined for 20 Eastern European Prunus dulcis cultivars (Halász et al., 2010a). Based on DNA sequences and fruit set analysis, two novel CIGs were proposed: group XXI $\left(S_{11} S_{31 \mathrm{H}}\right)$ and XXII $\left(S_{36} S_{37}\right)$. Five new alleles $\left(S_{31 \mathrm{H}}, S_{36}-S_{39}\right)$ were identified and several synonymous allele labels (e.g. $S_{12}=S_{\mathrm{k}}, S_{18}=S_{\mathrm{h}}, S_{23}=S_{\mathrm{i}}$ ) were also realized. As mentioned previously, Halász et al. (2008) described $S_{31}$ from the Hungarian cultivar, 'Tétényi bőtermö' while Kodad et al. (2008b) used the same label for an $S$-allele of 'Pou de Felanitx', a cultivar from Majorca Island. The two $S_{31}$-alleles do not match and so these labels are homonyms. Therefore, we proposed to use the label $S_{31 \mathrm{H}}$ for the $S_{31}$-RNase described from the Hungarian cultivar (Halász et al., 2008) and $S_{31 \mathrm{~S}}$ for the $S_{31}$-RNase described from the Spanish cultivar (Kodad et al., 2008b). The $S$-locus of almond suggested great genetic diversity of Eastern European germplasm. An SSR analysis was also carried out and it confirmed the overall great genetic diversity of almond originated in different geographic regions from Central Asia to Morocco (in preparation).

Nine almond selections developed at the Agricultural Research Service in Parlier, California were evaluated prior to decision on variety introduction (Mercure et al., 2013). Allelic profiles of almond accessions at the floral compatibility locus were also determined in our laboratory as part of a collaboration, since it is particularly important among self-incompatible accessions, as sharing an allele among pollination partner accessions reduces by $50 \%$ the amount of pollen useful for functional fertilization and nut set. Three of the five self-incompatible accessions and two of the self-compatible accessions evaluated in this test shared a single allele with 'Nonpareil'. Complete pollination incompatibility occurred with selection 82-73 and 'Nonpareil' (both being $S_{7} S_{8}$ ). The accession 5627-6 formed a novel CIG with late-blooming 'Titan' $\left(S_{8} S_{14}\right)$. We proposed to name this CIG XXVIII to continue labels after Ortega et al. (2006) and Kodad and Socias i Company (2009). The accession 23.5-16 carried an $S$-RNase allele that shared great similarity with $P$. tenella $S_{7}$-RNase and hence it was labelled $S_{t 7}$. We also detected signatures of introgressive hybridization in the region of Bademli (Turkey), where many of the wild-growing almond trees carried several $P$. webbii $S$-alleles (unpublished data). This phenomenon is expected to make $S$-genotyping efforts more complex and difficult as well as it points to the fact that hybridization among $P$. dulcis accessions and other closely related species might have contributed to the genetic variability of almond, as was also described by Delplancke et al. (2012).

\section{Japanese plum (Prunus salicina Lindl.)}

Japanese plum is a fruit crop with increasing popularity in many countries. Several North American cultivars have been introduced and fertility problems occurred within commercial orchards. Eleven cultivars of $P$. salicina including two pluots (complex hybrids between $P$. salicina and $P$. armeniaca) were genotyped. Our results clarified and harmonized two different (alphabetical and numerical) allele nomenclatures. The $S_{5}$-allele-specific primer (Sapir et al., 2004) can be used as a reliable marker for self-compatibility (SC) in Japanese plum. One CIG has been established (CIG VII, $S_{\mathrm{c}} S_{\mathrm{h}}$ ) and others were extended. A table was assembled including 49 cultivars assigned to I-VII CIGs. These data were used as the basis of worldwide classification of Japanese plum cultivars and was later completed by other studies (Guerra et al., 2009, 2010).

\section{European apricot (Prunus armeniaca L.)}

The $S$-genotypes of some US and Mediterranean cultivars had been determined before the start of our activity (Burgos et al., 1998). We performed three rounds of analyses: first we genotyped Central European and some Central Asian cultivars, then we analysed Turkish (Irano-Caucasian) apricots. Subsequently, we focused our analyses on the North African apricot germplasm. These regions are between the putative gene centres in Centre Asia or China and the main growing countries in the Mediterranean Europe.

Self-compatibility (SC) in apricot is due to a loss-offunction mutation within the pollen $S F B$ gene of the $S_{\mathrm{C}^{-}}$ haplotype. Controlled pollinations revealed that the cross 'Ceglédi óriás' $\left(S_{8} S_{9}\right) \times$ 'Ceglédi arany' $\left(S_{C} S_{9}\right)$ set well but the reciprocal cross did not. A multi-level approach including fruit set evaluation, pollen tube growth analysis, RNase activity assays, PCRs and DNA sequencing of the $S$-RNase and $S F B$ alleles clarified $S F B_{8}$ as the first known progenitor allele of a naturally occurring self-compatibility allele in Prunus, and consequently $S_{\mathrm{C}}$ could be considered as $S_{8}$ ' (Halász et al., 2007). A new co-dominant marker was designed based on PCR of $S F B$-alleles to allow high throughput identification of self-compatible apricot cultivars and selections. Besides Hungarian cultivars, the $S_{8}$-haplotype was also detected in some Turkish apricots but not in Western European cultivars. Results on the $S$-allele distribution within Turkey suggested that the mutation rendering the $S_{\mathrm{C}}$-haplotype non-functional might have occurred somewhere east from Central Turkey. In general, the genetic diversity of cultivated apricots decreases from east to west, a possible consequence of the emergence 
of the $S_{\mathrm{C}}$-haplotype and man-performed permanent selection for high and reliable yield. Allele frequency data and single nucleotide polymorphisms in the S-RNase gene helped to reconstruct putative dissemination routs of apricot selfcompatibility and clarify its crop evolutionary consequences including dramatic loss of genetic diversity in the European apricot germplasm (Pedryc et al., 2009; Bourguiba et al., 2012).

Thirteen $S$-alleles were identified and characterized from Eastern European and Asian apricots. Many Turkish cultivars were classified into new CIGs, III-XIV (Halász et al., 2010b), which was further completed by data from Tunisia (Lachkar et al., 2013) bringing the number of CIGs to 17. Among Turkish apricots only seven SC cultivars have been determined (Halász et al., 2010b). The fact that all five $S$-alleles detected in the Hungarian germplasm were also present in Turkish apricots, furnished molecular evidence supporting the long-suspected historical connection between Hungarian and Turkish apricots. The connection between these germplasm seems to be relatively recent. During the one and a half centuries of Ottoman occupation in Hungary, abundant records exist to document the admission of Turkish graft-wood and other propagation materials to Hungary (Faust et al., 1998). The imported Turkish material was likely exposed to both natural and human selection pressures that resulted in some landrace cultivars being well adapted to Hungarian ecological conditions and having valuable pomological characteristics. Our results confirmed that the Turkish germplasm had contributed considerably to the formation of several precious Hungarian apricot cultivars.

The realization of the shared $S$-allele pools of the IranoCaucasian and European apricots confirmed previous crop evolutionary hypotheses and phylogenetic data, which was further analyzed in the subsequent studies. First, the $S$-genotypes of 63 wild-growing Turkish apricots originated in the Erzincan region were determined by PCR amplification of the $S$-RNase intron regions and $S F B$ gene. Ten previously described and two new $S$-alleles (provisionally labelled as $S_{\mathrm{X}}$ and $S_{\mathrm{Y}}$ ) were identified in the genotypes. $S_{2}$ was the most frequent $S$-allele in the tested germplasm (occurred in 19 accessions), followed by $S_{8}(17), S_{19}(16), S_{3}(13), S_{12}(11), S_{6}$ (10) and $S_{7}$ (10), while each of the $S_{9}, S_{11}$ and $S_{13}$-alleles was found in 8 accessions (Halász et al., 2013). It may indicate that the most frequent alleles (e.g. $S_{2}$ and $S_{8}$ ) are free of $S$-linked genomic regions that are exposed to purifying selection. It is also further supported by the fact that mutations resulting in self-compatibility were declared both in the $S_{8}$ (Halász et al., 2007) and $S_{2}$-haplotypes (Vilanova et al., 2006). Although the dissemination of SC accessions was strongly favoured by human selection, potentially harmful alleles linked to the $S_{2}$ or $S_{8}$-haplotypes must have been manifested in the $S_{\mathrm{C}} S_{\mathrm{C}}$ or $S_{2} S_{2}$ homozygotes or $S_{\mathrm{C}} S_{8}$ heterozygotes. However, deleterious effects have not been detected in such genotypes (Vilanova et al., 2006; Halász et al., 2007). Similarly, only 2 S-alleles have been maintained in peach populations after the emergence of self-compatibility (Tao et al., 2007) compared to the many $S$-alleles described in almond, a self-incompatible species closely related to peach. In fact, self-compatible almond showed signs of inbreeding depression after self-pollination (Ortega et al., 2010). However, experimental confirmation is still required to accept that purifying selection acts on close proximity to specific $S$-alleles of apricot.

The $S_{\mathrm{C}}$-allele was not present in Erzincan indicating that all accessions are self-incompatible and $S_{8}$ was one of the most frequent alleles. It might suggest that $S_{\mathrm{C}}$ had emerged in another region like southern Turkey. When the $S$-genotypes of 55 Moroccan apricot accessions were determined, an unexpectedly great variability in the $S$-locus was detected. Several of these $S$-alleles $\left(S_{11}, S_{13}\right.$ and $\left.S_{20}\right)$ frequent in Morocco were also detected in the southern part of Turkey, a region close to the ancient Phoenicia. In addition, $S_{\mathrm{C}}, S_{8}, S_{11}$ and $S_{13}$ were also detected in local Tunisian cultivars (Lachkar et al., 2013), while they were not detected in western and southern Europe. All these surprising results gave strong support to the Irano-Caucasian origin of the Moroccan apricots and their introduction through North Africa (Kodad et al., 2013a).

The occurrence of self-compatibility in isolated environments such as several Moroccan oases (Kodad et al., 2013a,b) and selection pressure for high yielding genotypes resulted in the accumulation of the $S_{\mathrm{C}}$-allele, self-compatibility becoming predominant in such locations (Kodad et al., 2013a). This evolutionary trend was compared by the authors to that apricot faced in northern Europe. The European and Moroccan germplasm might have originated from different genetic bases, but reached a similar stage over time: the continuous pressure for self-compatibility by growers resulted in a serious loss of genetic diversity. These results contributed to the understanding of apricot crop history and highlighted the genome shaping force of sexual reproductive strategy in Prunus.

\section{Sweet cherry (Prunus avium L.)}

Most commercial cultivars have been $S$-genotyped excluding those grown at regions overlapping with the gene centre of sweet cherry (Tobutt et al., 2005). The Anatolian part of the Black sea coast is regarded as the centre of origin of cultivated sweet cherry. Eleven Turkish $P$. avium cultivars and 17 perspective selections growing wild at the Black Sea coast were $S$-genotyped (Szikriszt et al., 2013). All selections are regarded as perspective sources of resistance to fruit cracking. Eleven sweet cherry $\left(S_{1}-S_{7}, S_{10}\right.$ and $\left.S_{12}-S_{14}\right)$ and some wild cherry $\left(S_{17}-S_{19}, S_{21 / 25}\right.$ and $\left.S_{31}\right) S$-RNase alleles were detected. The results indicate Turkish cultivars represent a broader gene pool as compared with international cultivars. A new $\left(S_{37}\right)$ and a doubtful allele (provisionally labelled as $S_{7 \mathrm{~m}}$ ) as well as the sour cherry $S_{34}$-allele were identified in sweet cherry. These data and others (SSR variants within the $S_{13}$ RNase introns) confirmed that allele pools of sweet and sour cherry in the Black Sea region are overlapping. A new crossincompatibility group, XLV $\left(S_{2} S_{18}\right)$ was also proposed. The label of the group is somewhat doubtful at the moment since Schuster (2012) has published a compilation of available data and used this label for another group. Hence, the revision 
and harmonization of the CIG labels must be carried out in the future. Allele-specific primers were designed for $S_{17}-S_{19}$, $S_{21 / 25}, S_{34}$ and $S_{37}$. A phylogenetic analysis of the cherry $S_{31^{-}}$ RNase and its trans-specific sister alleles reliably mirrored the assumed length of the time period after the divergence of species in the subgenera Cerasus and Prunophora. Most variations (insertions/deletions and single nucleotide polymorphisms) in the $S$-RNase gene were silent and hence have not been exposed to natural selection.

A total of 8 different self-incompatibility genotypes were assigned to the 14 Ukrainian sweet cherry accessions tested (Hegedüs et al., 2013). Assigning cultivars to the appropriate incompatibility groups allowed the design of parental combinations which may result in new genotypes with enhanced functional properties (fruit antioxidant capacity and polyphenolics content) and other valuable fruit traits. Based on the $S$-genotypes, parental combinations were proposed to ensure $50 \%$ or $100 \%$ self-compatible seedlings in the offspring population. Our results demonstrated that adequate variation is available in the tested Ukrainian cherry germplasm for improving fruit health benefits in sweet cherry through hybridizations and $S$-genotyping helps to design crosses.

\section{Conclusion and future perspectives}

Our results provided information on $S$-allele diversity from regions between the main cultivation countries and the centres of origin of stone fruit species. The increased number of the $S$-alleles present in tree fruit accessions (landraces or trees growing wild, semi-wild) native to the regions from Eastern Europe to Central Asia holds considerable implications in relation with the development of $S$-genotyping methods, and also for cultivation and breeding. Information from the gene centres will surely increase our knowledge regarding the evolution of specific Prunus species during the following years. In addition, the absence or presence of specific $S$-alleles and their distribution over geographic regions provided valuable information on the evolution of fruit trees. Our research program is focused on both practical and theoretical implications of self-incompatibility of Prunus tree fruits. Our most recent achievement is the identification of a recently active non-autonomous transposable element that belongs to the Mutator transposase superfamily. Selfcompatibility of apricot was due to the integration of such a transposon.

\section{Acknowledgements}

This work was funded by the OTKA PD78124 project and also supported by the János Bolyai Research Scholarship of the Hungarian Academy of Sciences.

\section{References}

Boskovic, R., Tobutt, K.R., Batlle, I. \& Duval, H. (1997): Correlation of ribonuclease zymograms and incompatibility genotypes in almond. Euphytica, 97: 167-176.

Bourguiba, H., Audergon, J.M., Krichen, L., Trifi-Farah, N., Mamouni, A., Trabelsi, S., D’Onofrio, C., Asma, B.M., Santoni, S. \& Khadari, B. (2012): Loss of genetic diversity as a signature of apricot domestication and diffusion into the Mediterranean Basin. BMC Plant Biol.

Burgos, L., Pérez-Tornero, O., Ballester, J. \& Olmos, E. (1998): Detection and inheritance of stylar ribonucleases associated with incompatibility alleles in apricot. Sex. Plant Reprod., 11: 153-158.

Delplancke, M., Alvarez, N., Espíndola, A., Joly, H., Benoit, L., Brouck, E. \& Arrigo, N. (2012): Gene flow among wild and domesticated almond species: insights from chloroplast and nuclear markers. Evol. Appl., 5: 317-329.

Entani, T., Iwano, M., Shiba, H., Che, S.F., Isogai, A. \& Takayama, S. (2003): Comparative analysis of the self-incompatibility $(S$ - $)$ locus region of Prunus mume: identification of a pollen-expressed F-box gene with allelic-diversity. Genes Cells, 8: 203-213.

Faust, M., Surányi, D. \& Nyujtó, F. (1998): Origin and dissemination of apricot. Hort. Rev., 22: 225-266.

Guerra, M.E., Rodrigo, J., López-Corrales, M. \& Wünsch, A. (2009): $S$-RNase genotyping and incompatibility group assignment by PCR and pollination experiments in Japanese plum. Plant Breed., 128: 304-311.

Guerra, M.E., Rodrigo, J., Wünsch, A. \& López-Corrales, M. (2010): Self-incompatibility in Japanese plum $-S$-allele genotyping of cultivars. Acta Hort. (ISHS), 874: 169-174

Halász, J., Fodor, Á., Hegedüs, A. \& Pedryc, A. (2008): Identification of a new self-incompatibility allele $\left(S_{31}\right)$ in a Hungarian almond cultivar and its reliable detection. Sci. Hortic., 116: 448-451.

Halász, J., Fodor, A., Pedryc, A. \& Hegedűs, A. (2010a): $S$-genotyping of Eastern European almond cultivars: identification and characterization of new $\left(S_{36}-S_{39}\right)$ self-incompatibility ribonuclease alleles. Plant Breed., 129: 227-232.

Halász, J., Hegedüs, A., Szikriszt, B., Ercisli, S., Orhan, E. \& Ünlü, H.M. (2013): The $S$-genotyping of wild-growing apricots reveals only self-incompatible accessions in the Erzincan region of Turkey. Turk. J. Biol., 37: 733-740.

Halász, J., Pedryc, A., Ercisli, S., Yilmaz, K.U. \& Hegedüs, A. (2010b): $S$-genotyping supports the genetic relationships between Turkish and Hungarian apricot germplasm. J. Amer. Soc. Hort. Sci., 135: 410-417.

Halász, J., Pedryc, A. \& Hegedüs, A. (2007): Origin and dissemination of the pollen-part mutated $S_{\mathrm{C}}$-haplotype that confers self-compatibility in apricot (Prunus armeniaca). New Phytol., 176: 792-803.

Halász, J., Szikriszt, B., Ercisli, S., Yilmaz, K.U., Dogan, A., Szabó, Z., Nyéki, J., Pedryc, A. \& Hegedüs, A. (2012): $S$-locus genotyping on stone fruits. Acta Hort., 967: 113-119.

Hegedüs, A., Taller, D., Papp, N., Szikriszt, B., Ercisli, S., Halász, J. \& Stefanovits-Bányai É. (2013): Fruit antioxidant capacity and self-incompatibility genotype of Ukrainian sweet cherry (Prunus 
avium L.) cultivars highlight their breeding prospects. Euphytica, 191: 153-164.

Kodad, O., Alonso, J.M., Sánchez, A., Oliveira, M. \& Socias I Company, R. (2008a): Evaluation of genetic diversity of $S$-alleles in an almond germplasm collection. J. Hort. Sci. Biotechnol., 83: 603-608.

Kodad, O., Halász, J., Hegedűs, A., Messaoudi, Z., Pedryc, A. \& Socias I Company, R. (2013b): Self-(in)compatibility and fruit set in 19 local Moroccan apricot (Prunus armeniaca L.) genotypes. J. Hort. Sci. Biotechnol., 88: 457-461.

Kodad, O., Hegedús, A., Socias i Company, R. \& Halász, J. (2013a): Self-(in)compatibility genotypes of Moroccan apricots indicate differences and similarities in the crop history of European and North African apricot germplasm. BMC Plant Biol., 13: 196.

Kodad, O., Sánchez, A., Saibo, N., Oliveira, M. \& Socias I Company, R. (2008b): Identification and characterization of new $S$-alleles associated with self-incompatibility in almond. Plant Breed., 127: 632-638.

Kodad, O. \& Socias I Company, R. (2009): Review and update of self-incompatibility alleles in almond. Acta Hort., 814: 421-424.

Lachkar A., Fattouch S., Ghazouani T., Halasz J., Pedryc A., Hegedus A. \& Mars M. (2013): Identification of self-(in) compatibility $S$-alleles and new cross-incompatibility groups in Tunisian apricot (Prunus armeniaca L.) cultivars. J. Hort. Sci. Biotechnol., 88: 497-501.

McClure, B.A., Haring, V., Ebert, P.R., Anderson, M.A., Simpson, R.J., Sakiyama, F. \& Clarke, A.E. (1989): Style selfincompatibility gene products of Nicotiana alata are ribonucleases. Nature, 342: 955-957.

Mercure, E., Halász, J., Hegedús, A. \& Ledbetter, C. (2013): Yield, pollination aspects and kernel qualities of almond (Prunus dulcis) selections trialed in the southern San Joaquin Valley. J. Am. Pom. Soc., 67: 126-134.

Ortega, E., Boskovic, R.I., Sargent, D.J. \& Tobutt, K.R. (2006): Analysis of S-RNase alleles of almond (Prunus dulcis): characterization of new sequences, resolution of synonyms and evidence of intragenic recombination. Mol. Genet. Genom., 276: 413-426.

Ortega, E., Martínez-García, P., Dicenta, F. \& Egea, J. (2010): Disruption of endosperm development: an inbreeding effect in almond (Prunus dulcis). Sex. Plant Reprod., 23: 135-140.

Pedryc, A., Ruthner, Sz., Hermán, R., Krska, B., Hegedűs, A. \& Halász, J. (2009): Genetic diversity of apricot revealed by a set of SSR markers from linkage group G1. Sci. Hortic., 121: 19-26.

Sapir, G., Stern, R.A., Eisikowitch, D. \& Goldway, M. (2004): Cloning of four new Japanese plum $S$-alleles and determination of the compatibility between cultivars by PCR analysis. J. Hortic. Sci. Biotech., 79: 223-227.

Schuster, M. (2012): Incompatible ( $S$-) genotypes of sweet cherry cultivars (Prunus avium L.). Sci. Hortic., 148: 59-73.

Szikriszt, B., Doğan, A., Ercisli, S., Akcay, M.E., Hegedüs, A. \& Halász, J. (2013): Molecular typing of the self-incompatibility locus of Turkish sweet cherry genotypes reflects phylogenetic relationships among cherries and other Prunus species. Tree Genet. Genomes, 9: 155-165.

Tao, R., Watari, A., Hanada, T., Habu, T., Yaegaki, H., Yamaguchi, M. \& Yamane, H. (2007): Self-compatible peach (Prunus persica) has mutant versions of the $S$ haplotypes found in self-incompatible Prunus species. Plant Mol. Biol., 63: 109-123.

Tobutt, K.R., Sonneveld, T., Bekefi, Z. \& Bošković, R. (2005): Cherry (in)compatibility genotypes - an updated cultivar table. Acta Hort., 663: 667-671.

Ushijima, K., Sassa, H., Dandekar, A.M., Gradziel, T.M., Tao, R. \& Hirano, H. (2003): Structural and transcriptional analysis of the self-incompatibility locus of almond: identification of a pollenexpressed $F$-box gene with haplotype-specific polymorphism. Plant Cell, 15: 771-781.

Vilanova, S., Badenes, M.L., Burgos, L., Martínez-Calvo, J., Llácer, G. \& Romero, C. (2006): Self-compatibility of two apricot selections is associated with two pollen-part mutations of different nature. Plant Physiol., 142: 629-641. 